\title{
Characterization of a new highly sensitive immunometric assay for thyroglobulin with reduced interference from autoantibodies
}

\author{
Marianne Nordlund Broughton ${ }^{1} \cdot$ Ragnhild Nome $^{1} \cdot$ Ingvill Sandven $^{1} \cdot$ Elisabeth Paus $^{1}$ • \\ Trine Bjøro ${ }^{1,2}$
}

Received: 6 October 2015 / Accepted: 7 December 2015 /Published online: 22 December 2015

(C) The Author(s) 2015. This article is published with open access at Springerlink.com

\begin{abstract}
Measurements of serum thyroglobulin (Tg) with sensitive immunoassays are of great importance for the management of patients with differentiated thyroid carcinomas. However, interference of circulating autoantibodies to $\mathrm{Tg}$ (hTgAb) hampers the usefulness of most assays. We have produced a panel of monoclonal antibodies (mAbs) selected to bind $\mathrm{Tg}$ in the presence of $\mathrm{Tg}$ autoantibodies and developed a sensitive immunoassay for $\mathrm{Tg}$ with minor interference by hTgAbs. The antibodies were characterized by crossinhibition and immunoassay combination studies, as well as affinity estimation. The within-run and total imprecision of the assay were determined with 2664 samples in 60 separate runs. The most sensitive assay combination with superior protection against autoantibodies consisted of two solid phase mAbs and two tracer mAbs with distinct binding sites. The assay was linear and displayed a wide dynamic range up to $1342 \mu \mathrm{g} / \mathrm{l}$ with a functional sensitivity of $0.1 \mu \mathrm{g} / \mathrm{l}$ and a total imprecision of less than $10 \%$. There was good agreement between the new high sensitive immunofluorometric assay (IFMA) and two well-established Tg assays from Brahms Kryptor and Roche Diagnostics. Mean difference between the new IFMA and the Kryptor assay was $0.059 \mu \mathrm{g} / \mathrm{l}$ with a $95 \%$ confidence interval of -0.032 to $0.151 \mu \mathrm{g} / \mathrm{l}$, whereas the mean difference between
\end{abstract}

Electronic supplementary material The online version of this article (doi:10.1007/s13277-015-4597-2) contains supplementary material, which is available to authorized users.

Marianne Nordlund Broughton mnordl@ous-hf.no

1 Department of Medical Biochemistry, Radiumhospitalet, Oslo University Hospital (OUH), Oslo, Norway

2 Institute of Clinical Medicine, University of Oslo, Oslo, Norway the new IFMA and the Roche assay was $-0.80 \mu \mathrm{g} / \mathrm{l}$ with a $95 \%$ confidence interval of -1.24 to $-0.35 \mu \mathrm{g} / \mathrm{l}$.

Keywords Thyroid carcinoma - Thyroglobulin . Autoantibodies $\cdot$ Immunoassay $\cdot$ Time-resolved

\section{Introduction}

Thyroglobulin (Tg) is a $670-\mathrm{kDa}$ glycoprotein produced specifically by the follicular cells of the thyroid gland. The $\mathrm{Tg}$ molecule consists of two identical subunits which undergo extensive posttranslational modification including glycolsylation, phosphorylation, sulfation, and iodination [1, 2]. Ultimately, thyroglobulin functions as a prohormone for the thyroid hormones thyroxine $\left(\mathrm{T}_{4}\right)$ and triiodothyronine $\left(T_{3}\right)$, but it is also released from the thyroid gland and is detectable in sera of most normal individuals.

The incidence of thyroid cancer has increased by $50 \%$ over the past 25 years $[3,4]$. The most important clinical application of an immunoassay for thyroglobulin is in the follow-up of patients with differentiated thyroid cancer (DTC) which have undergone total thyroidectomy. DTCs are often diagnosed in the early decades of life, and recurrences can occur many years after the primary treatment, necessitating life-long monitoring with clinical examinations and serial serum $\mathrm{Tg}$ measurements. The reoccurrence of serum $\mathrm{Tg}$ after thyroidectomy and 131-iodine ablation strongly indicates metastatic disease, and small elevation in the $0.2 \mu \mathrm{g} / \mathrm{l}$ range can be of pathological significance. The treatment and follow-up of this patient group have also changed, and the American Thyroid Association guidelines suggest that $\mathrm{Tg}$ assays with functional sensitivity of $\sim 0.1 \mu \mathrm{g} / \mathrm{l}$ may reduce the need to perform TSHstimulated Tg measurements during the initial follow-up of some patients [5-7]. Thus, the sensitivity of the assay is very 
important for its clinical usefulness. Another challenge is assay interference by human autoantibodies against thyroglobulin (TgAb). In immunometric assays, these autoantibodies can cause an underestimation of the thyroglobulin concentration and, consequently, reduce the usefulness of $\mathrm{Tg}$ in the follow-up of these patients. Circulating autoantibodies to $\mathrm{Tg}$ are often positive in patients with autoimmune thyroid diseases, Hashimoto's thyroiditis (HT), and Graves' disease (GD), but TgAbs can also be detected in patients with thyroid carcinoma and in individuals with no apparent thyroid disease. It has been shown that $\mathrm{Tg}$ autoantibodies are detected in approximately $20 \%$ of patients with thyroid cancer and in approximately $10 \%$ of normal individuals [8]. To reveal TgAb interference in $\mathrm{Tg}$ assays, there are guidelines recommending reliable $\mathrm{TgAb}$ detection prior to $\mathrm{Tg}$ testing by immunoassays [8]. A negative $\mathrm{TgAb}$ test is used to verify the absence of $\mathrm{TgAb}$ interference, whereas a positive $\mathrm{TgAb}$ test indicates that the $\mathrm{Tg}$ concentration measured in the immunoassay may be unreliable and give a falsely low/undetectable serum Tg concentration that could mask disease. This could have serious consequences for the follow-up of patients with DTC which have undergone total thyroidectomy, and unfortunately, it has been reported that false-negative $\mathrm{TgAb}$ misclassification was $30-40 \%$ using manufacturer-recommended TgAb cutoffs [9]. Thus, there is a clear need for a new, improved, and highly sensitive immunoassay for $\mathrm{Tg}$ with less interference by $\mathrm{Tg}$ autoantibodies.

Here we describe the production of a panel of monoclonal antibodies selected to bind $\mathrm{Tg}$ in the presence of human autoantibodies from cancer patients. We have further characterized the antibody specificities and tested suitable antibody pairs for construction of an immunofluorometric assay (IFMA) for Tg. The assay was finally compared to two well-established immunoassays for Tg (Brahms Kryptor and Roche Diagnostics).

\section{Materials and methods}

\section{Production of monoclonal antibodies}

Female BALB/c mice (6-8 weeks of age; Harlan Olac Ltd., Oxon, UK) were primed by subcutaneous injections with $25 \mu \mathrm{g}$ Tg emulsified in Freund's complete adjuvant (for antigen preparation see Supplemental data). Two booster immunizations of $30 \mu \mathrm{g}$ of Tg (subcutaneous) in Freund's incomplete adjuvant were given 2-3 and 4-5 months later. One month after the last boost immunization dose, four daily intraperitoneal boosts of 50-200 $\mu \mathrm{g}$ of Tg were given immediately before splenectomy [10]. Experimental animals were treated in accordance with institutional guidelines. Specific immune response was determined by incubating $100 \mu$ diluted blood samples from immunized mice with $100 \mu{ }^{125}$ I-labelled $\mathrm{Tg}$ (approximately 50,000 cpm) in $0.05 \mathrm{M}$ Tris- $\mathrm{HCl}$ buffer $\mathrm{pH}$
7.8 containing $1 \%$ bovine serum albumin (BSA). Incubation was performed at room temperature before free and bound antigen was separated using sheep anti-mouse antibodies (SAM) coupled to paramagnetic polymer particles (Dynabeads M280, Life Technologies, Oslo, Norway), by adding $100 \mu \mathrm{l}$ of a $10 \mathrm{mg} / \mathrm{ml}$ suspension. The resulting hybridomas were screened for anti-Tg monoclonal antibodies in absence and presence of human anti-thyroglobulin antibodies (for primary and secondary screening procedures, see Supplemental data) [11]. After the second screening, hybridomas were subcloned and selected clones were chosen for further in vitro expansion. Antibodies were purified by Protein A-Sepharose 4B (GE Healthcare Life Sciences, Uppsala, Sweden) chromatography. Subtyping of mAbs was performed using the IsoStrip Mouse Monoclonal Antibody Isotyping Kit (Roche, Indianapolis, IN, USA).

\section{Measuring human autoantibodies to $\mathbf{T g A b}$}

Human $\mathrm{TgAb}$ was analyzed using a competitive assay (Brahms Kryptor, Henningsdorf, Germany) with a measuring range between 10 and $850 \mathrm{kU} / \mathrm{l}$. When $\mathrm{TgAb}$ levels were above $850 \mathrm{kU} / \mathrm{l}$, the samples were automatically diluted and the measuring range for automatically dilution was $10-20$, $000 \mathrm{kU} / 1$.

\section{Radiolabelling of $\mathrm{Tg}$}

Thyroglobulin and antibodies were iodinated by the indirect iodogen method (Pierce, Rockford, IL, USA) with $\mathrm{Na}^{125} \mathrm{I}$ (Amersham Pharmacia Biotech, Little Chalfont, UK) at an equal molar ratio of protein to iodine. Iodinated protein was stored at $-20^{\circ} \mathrm{C}$ in $50 \%$ ethylene glycol and $0.05 \mathrm{M}$ Tris- $\mathrm{HCl}$ buffer $\mathrm{pH} 7.8$ containing $1 \mathrm{~g} / 1 \mathrm{BSA}$.

\section{Conjugation of tracer antibodies with $\mathrm{Eu}^{3+}$-chelates}

Purified antibodies were conjugated to a europium chelate using the DELFIA Eu ${ }^{3+}$-Labelling kit (PerkinElmer Inc., Turku, Finland). The antibodies were labelled at room temperature for $72 \mathrm{~h}$ with a 12.5 -fold molar excess of the $\mathrm{Eu}^{3+}$ chelate in $0.1 \mathrm{M}$ Na-borate buffer, $\mathrm{pH}$ 8.6. Excess label was removed by gel filtration on a PD 10 column (GE Healthcare Life Sciences, Uppsala, Sweden) equilibrated with $0.05 \mathrm{M}$ Tris- $\mathrm{HCl}$ and $0.5 \mathrm{~g} / \mathrm{NaN}_{3}$ (pH 7.8). The stock conjugate was stored at $4{ }^{\circ} \mathrm{C}$ in the Tris buffer. Before use, the stock solution was further diluted to $50 \mu \mathrm{g} / \mathrm{ml}$ in a Tris buffer containing $75 \mathrm{mg} / \mathrm{ml}$ of diethylenetriamine pentaacetic acidtreated BSA (PerkinElmer Inc., Turku, Finland) and filtered through a $0.22-\mu \mathrm{m}$ sterile filter (GE Healthcare Life Sciences, Germany). 


\section{Preparation of $\mathrm{F}\left(\mathrm{ab}^{\prime}\right)_{2}$ fragments}

Monoclonal antibodies were fragmented essentially according to the method of Milenic et al. [12]. Antibody in $0.05 \mathrm{M}$ Tris buffer $\mathrm{pH} 7.0$ containing $0.1 \mathrm{M} \mathrm{NaCl}$ and $0.005 \mathrm{M}$ EDTA was incubated at $37{ }^{\circ} \mathrm{C}$ for $2 \mathrm{~h}$ with bromelain (ID-Diluent 1; DiaMed AG, Switzerland) in a weight ratio of 20:1. The enzymatic reaction was stopped by the addition of $1 / 10$ volume of freshly made $0.2 \mathrm{M} \mathrm{N}$-ethyl maleimide. Products were purified at $4{ }^{\circ} \mathrm{C}$ on a protein A chromatography column equilibrated with $0.1 \mathrm{M}$ sodium phosphate buffer $\mathrm{pH} 8.2$ and eluted with a linear $\mathrm{pH}$ gradient from the $\mathrm{pH} 8.2$ application buffer to a pH 3.2 limit buffer $\left(0.025 \mathrm{M}\right.$ citric acid, $0.025 \mathrm{NaH}_{2} \mathrm{PO}_{4}$, and $\left.0.1 \mathrm{~g} / \mathrm{NaN}_{3}\right)$. Purified $\mathrm{F}\left(\mathrm{ab}^{\prime}\right)_{2}$ fragments were dialyzed against $0.1 \mathrm{M}$ sodium borate buffer $\mathrm{pH}$ 8.0.

\section{Biotinylation of $F\left(a b^{\prime}\right)_{2}$ and IgG capture antibodies}

A fivefold molar excess of EZ-link Sulfo-NHS-LC Biotin (Thermo Scientific, Rockford, USA) was added to the antibodies contained in $0.15 \mathrm{M} \mathrm{NaCl}$ and $0.1 \mathrm{M}$ sodium borate (pH 8.0) and incubated for $30 \mathrm{~min}$ at room temperature. The reaction was stopped by adding $1 \mathrm{M}$ glycine, and free biotin was removed by dialysis against $0.005 \mathrm{M}$ Tris- $\mathrm{HCl}, 0.15 \mathrm{M}$ $\mathrm{NaCl}$, and $0.5 \mathrm{~g} / 1 \mathrm{NaN}_{3}(\mathrm{pH} 7.8)$ or by gel filtration on a PD 10 column equilibrated with the Tris buffer. The final solution was diluted to $50 \mu \mathrm{g} / \mathrm{ml}$ and filtered through a $0.22-\mu \mathrm{m}$ sterile filter.

\section{Epitope mapping}

Epitope mapping and grouping of antibodies were performed by cross-inhibition, where binding of $\mathrm{mAbs}$ to the antigen was performed in the absence of competing mAbs (reference signal) or in the presence of competing mAbs. Iodinated $\mathrm{Tg}(50$, $000 \mathrm{cpm}$, approximately $20 \mathrm{ng}$ ) was allowed to react for $1 \mathrm{~h}$ with $1 \mu \mathrm{g}$ competing mAbs $(100 \times$ molar excess $)$ in PBS containing $10 \mathrm{~g} / \mathrm{l} \mathrm{BSA}$. After incubation, $100 \mu \mathrm{l}$ was transferred to breakapart microtiter wells coated with mAbs $(1 \mu \mathrm{g} /$ well). The plates were incubated for $1 \mathrm{~h}$ with shaking and then washed three times with wash solution, before counting of bound radioactivity. Binding of ${ }^{125} \mathrm{I}-\mathrm{Tg}$ without inhibiting antibody was used as a reference for each solid phase antibody, and complete cross-inhibition was defined as $>80 \%$ inhibition.

\section{Affinity measurements}

Dissociation constants $\left(K_{\mathrm{D}}\right)$ for the monoclonal antibodies were estimated from the concentration of free antibody (in $\mathrm{mol} / \mathrm{l}$ ) needed to achieve half-maximal binding of Tg. Tubes containing $100 \mu \mathrm{l}^{125} \mathrm{I}-\mathrm{Tg}$ in $0.05 \mathrm{~mol} / \mathrm{l}$ Tris-HCl with $0.1 \mathrm{~mol} / \mathrm{l} \mathrm{NaCl}$ and $0.1 \%$ BSA were incubated with $100 \mu \mathrm{l}$ of increasing amounts (0.32-1000 ng/tube) of the antibodies diluted in the same buffer. Free and bound antigen was separated with an excess of sheep anti-mouse antibody coupled to magnetizable polymer particles (Dynabeads M280; Life Technologies, Oslo, Norway) followed by washing and counting of radioactivity.

\section{Surface plasmon resonance analysis}

The binding kinetics of the Tg antibodies were determined by surface plasmon resonance (SPR) using the BIAcore3000 SPR biosensor (Biacore Life Sciences, Little Chalfont, UK). $\mathrm{Tg}$ antibodies were immobilized at low densities (between 100 and 200 resonance units (RU)) to CM5 chips using the amino coupling protocol recommended in the BIApplications Handbook. Tg was diluted in running buffer $(0.01 \mathrm{M}$ Hepes $\mathrm{pH} 7.4,0.15 \mathrm{M} \mathrm{NaCl}, 0.003 \mathrm{M}$ EDTA, and $0.005 \%$ Surfactant P20) to five concentration levels ( $0.3-25 \mathrm{nM})$ and injected sequentially with increasing concentration in a single cycle at a flow rate of $50 \mu \mathrm{l} / \mathrm{min}$. The $\mathrm{Tg}$ association was allowed to proceed for $180 \mathrm{~s}$ followed by dissociation for $180 \mathrm{~s}$. The temperature was kept constant at $25^{\circ} \mathrm{C}$ in all runs. The reference surface, a flow cell treated with binding buffer without antigen, was used to correct for systematic noise and instrument drift in every run. Also, prior to each Tg binding cycle, buffer was injected for additional correction. The binding kinetics was calculated using the BIAevaluation software version 4.1. Association and dissociation rate constants $\left(k_{\mathrm{a}}\right.$ and $k_{\mathrm{d}}$ ) were determined by single cycle titration using the simple biomolecular interaction model $(A+B=A B)$ and corrected for mass transfer.

\section{Immunometric assays for thyroglobulin}

Initial testing was performed with immunoradiometric assays (see Supplemental data). Further testing was performed with time-resolved immunofluorometric assays (TR-IFMAs).

Assay format The TR-IFMAs for $\mathrm{Tg}$ were performed in streptavidin-coated 96-well microtiter plates with biotinylated $\mathrm{mAbs}$ on solid phase and $\mathrm{Eu}^{3+}$-conjugated tracer mAbs. For assaying samples, $200 \mu \mathrm{g} / \mathrm{well}$ of biotinylated $\mathrm{mAb}$ in $200 \mu \mathrm{l}$ DELFIA assay buffer $(0.05 \mathrm{M}$ Tris- $\mathrm{HCl}, 0.05 \mathrm{M} \mathrm{NaCl}$, $0.02 \mathrm{M}$ diethylene triamine penta acetic acid, $0.5 \mathrm{~g} / \mathrm{N} \mathrm{NaN}_{3}$, $0.1 \mathrm{ml} / 1$ Tween 20, $20 \mathrm{mg} / \mathrm{l}$ Amaranth, $0.5 \mathrm{~g} / 1 \mathrm{BSA}, 0.5 \mathrm{~g} / \mathrm{l}$ bovine IgG, and $15 \mathrm{mg} / \mathrm{l}$ MAK33-IgG (Roche Applied Science, Penzberg, Germany), $\mathrm{pH}$ 7.8) was incubated under continuous shaking for 45 min before washing three times with wash solution $(0.05 \mathrm{M}$ Tris- $\mathrm{HCl}, 0.15 \mathrm{M} \mathrm{NaCl}, 0.05 \%$ Tween 20, $0.1 \%$ Germall, $\mathrm{pH}$ 7.8). Fifty microliters of calibrator or sample and $100 \mu$ lassay buffer were then added to duplicate wells, followed by continuous shaking for $60 \mathrm{~min}$. Following three washes, $200 \mu \mathrm{g} / \mathrm{well}$ of $\mathrm{Eu}^{3+}$-labelled $\mathrm{mAb}$ in 
$200 \mu 1$ DELFIA assay buffer was added and plates incubated for another $60 \mathrm{~min}$ with continuous shaking. After six washes, $200 \mu \mathrm{l} /$ well of enhancement solution was added, followed by incubation with shaking at room temperature for $5 \mathrm{~min}$. Fluorescence was measured in a time-resolved fluorometer (Victor, PerkinElmer Inc., Turku, Finland).

Analytical recovery The ability of the various assays to detect $\mathrm{Tg}$ in the absence and presence of human antithyroglobulin antibodies (TgAb) was tested by preincubation of $180 \mu \mathrm{l}$ of a Tg standard of approximately $18 \mu \mathrm{g} / \mathrm{l}$ with $20 \mu \mathrm{l}$ of individual sera containing human $\mathrm{TgAb}$ ranging from 261 to $1756 \mathrm{kU} / 1$ or a pool of 35 different sera each containing $>500 \mathrm{kU} / 1$ of human TgAb. The total concentration of TgAb in the pool of sera was $7225 \mathrm{kU} / 1$. A sample of standard matrix buffer $(0.05 \mathrm{M}$ Tris- $\mathrm{HCl}, 0.15 \mathrm{M}$ $\mathrm{NaCl}, 1 \mathrm{~g} / \mathrm{l}$ Germall containing $60 \mathrm{~g} / \mathrm{l} \mathrm{BSA}, \mathrm{pH}$ 7.4) replacing the $\mathrm{TgAb}$ fraction served as the reference.

Multiple antibodies combined in the assays Antibody combinations were investigated using the IFMA procedure described above. When two or three antibodies were tested simultaneously as solid phase, $0.1 \mu \mathrm{g} / \mathrm{well}$ of each antibody was applied. Similarly, half of the concentration for Eu tracer was applied if two antibodies were tested in one assay. The final assay variants were performed on an automated AutoDelfia instrument.

\section{Calibrators and controls}

The calibrators were based on purified Tg obtained from human goiter tissue, as described above. Calibrators containing $0,0.91,3.4,16.6,94.5,442$, and $1342 \mu \mathrm{g} / 1 \mathrm{Tg}$ were prepared by dilution of the purified $\mathrm{Tg}$ fraction in matrix buffer, and the dilutions were standardized against the certified reference material (CRM) 457 reference preparation and stored at $-20{ }^{\circ} \mathrm{C}$ in aliquots. After thawing, the calibrators were stored at $4{ }^{\circ} \mathrm{C}$ and used within 2 weeks.

Control samples were PreciControls Tumor Marker from Roche Diagnostics, at two levels, 0.5 and $45 \mu \mathrm{g} / \mathrm{l}$, respectively, and from pooled serum of thyroidectomized patients, with value in the low range of approximately $0.2 \mu \mathrm{g} / \mathrm{l}$. The control samples were included in every run and analyzed in duplicate before and after the patient samples.

\section{The final TR-IFMA for Tg}

The final assay for Tg was performed with two solid phase antibodies (E40 and I24) and two tracer mAbs (E44 and E45). The solid phase mAbs were modified to biotinylated $\left(\mathrm{Fab}^{\prime}\right)_{2}$ fragments, and the tracer mAbs were conjugated to the $\mathrm{Eu}^{3+}$ chelate, as described in earlier sections. For assaying samples, we used $100 \mathrm{ng} /$ well of each biotinylated mAb and $100 \mathrm{ng} /$ well of each tracer mAb, and the assay was further performed as described above.

Detection limit The limit of blank (LoB) and limit of detection (LoD) were determined according to Clinical Laboratory Standards Institute (CLSI) Guideline EP17-A [13]. LoB was defined as the mean of zero calibrator +1.645 times the standard deviation (SD) and calculated from 77 replicates. LoD was defined as $\mathrm{LoB}+1.645$ times the $\mathrm{SD}$ of a sample containing low concentration of $\mathrm{Tg}(0.26 \mu \mathrm{g} / \mathrm{l})$ and calculated from 105 replicates.

Functional sensitivity, precision, and linearity The functional sensitivity was defined as the lowest $\mathrm{Tg}$ concentration measured with coefficient of variation (CV) of $20 \%$. The within-run and total imprecision of the assay were determined with 2664 samples in 60 separate runs. The concentrations of the samples were measured in duplicates using different lots of reagents and calibrators, and the testing period was 9 months. Total imprecision was defined as the $\mathrm{CV}$ of all measured concentrations in all assay runs and calculated using MultiCalc ${ }^{\mathrm{TM}}$ software. To determine the linearity on dilution, we performed serial dilution of a serum sample with elevated Tg concentration $(>1800 \mu \mathrm{g} / \mathrm{ml})$. The sample was diluted 2-, 10-, 50-, 250-, $1250-$, and 6250-fold in calibration buffer. The measurements were done in duplicate.

\section{Patient samples}

Two thousand six hundred sixty-four fresh serum samples from the hospital routine laboratory were analyzed in our new highly sensitive $\mathrm{Tg}$ (hsTg) assay. Out of these, 1218 had $\mathrm{Tg}$ concentration $<0.91 \mu \mathrm{g} / \mathrm{l}, 281$ had $\mathrm{Tg}$ concentration between 0.91 and $3.4 \mu \mathrm{g} / \mathrm{l}, 553 \mathrm{had} \mathrm{Tg}$ concentration between 3.4 and $16.6 \mu \mathrm{g} / 1,277 \mathrm{had} \mathrm{Tg}$ concentration between 16.6 and $94.5 \mu \mathrm{g} / \mathrm{l}, 159 \mathrm{had} \mathrm{Tg}$ concentration between 94.5 and $442 \mu \mathrm{g} / \mathrm{l}$, and $176 \mathrm{had} \mathrm{Tg}$ concentration between 442 and $1342 \mu \mathrm{g} / \mathrm{l}$.

In addition, 241 serum samples from 105 patients with DTC (papillary or follicular thyroid cancer) were analyzed simultaneously in our assay, a homogenous assay (Brahms Kryptor, Henningsdorf, Germany) with a measuring range between 0.09 and $200 \mu \mathrm{g} / \mathrm{l}$ and an electrochemiluminescence immunoassay (Roche Diagnostics, Penzberg, Germany) with a measuring range between 0.04 and $500 \mu \mathrm{g} / \mathrm{l}$. The samples were collected as part of the routine sampling procedure in follow-up after treatment of DTC in our hospital from 2009 to 2010. Seventy-four of the patients had undergone rhTSH stimulation and had low initial $\mathrm{Tg}$ values and negative/low values of human $\operatorname{TgAb}(<50 \mathrm{kU} / \mathrm{l})$. We analyzed two to three samples per patient, resulting in a total of 210 samples. The final 31 samples were from 31 randomly selected patients with measurable $\mathrm{Tg}$ values and 
$\mathrm{TgAb}$ between 50 and $2934 \mathrm{kU} / \mathrm{l}$. All samples were stored at $-30{ }^{\circ} \mathrm{C}$. Every participant had given written informed consent to participate in the study, and The Regional Committee for Medical Research Ethics approved the study.

\section{Statistical analysis}

Spearman correlation and Deming regression analysis were performed to compare the new assays with the two established $\mathrm{Tg}$ assays from Brahms Kryptor and Roche Diagnostics. The $\mathrm{Tg}$ values were log-transformed to obtain normal distribution, and value $<0.04 \mu \mathrm{g} / \mathrm{l}$ was set to $0.03 \mu \mathrm{g} / \mathrm{l}$.

\section{Results}

\section{Monoclonal antibody characteristics}

Several monoclonal antibodies to thyroglobulin were obtained after screening approximately 2000 hybridomas from two individual fusions. From the secondary screening, nine antibodies were selected according to their ability to bind $\mathrm{Tg}$ in the presence of anti-thyroglobulin autoantibodies. These antibodies were subcloned and purified on a protein A column. The purified antibodies were IgG subtyped. Six antibodies (E40, $\mathrm{E} 44, \mathrm{E} 47, \mathrm{I15}$, I24, and I25) were of the IgG1 subtype, while three (E39, E41, and E45) were of the $\operatorname{IgG} 2_{b}$ subclass. All possessed kappa light chains.

\section{Epitope mapping}

Characterization of which antibodies that was able to bind simultaneously to thyroglobulin was evaluated by crossinhibition assays. Binding of the monoclonal antibodies to $\mathrm{Tg}$ was performed in the presence of inhibiting $\mathrm{mAbs}$ already bound to labelled antigen and in the absence of mAbs (reference signal), see Table 1. From the inhibition pattern, it was possible to classify the monoclonal antibodies into five epitope groups: A to E. Group D may be further subdivided because E39 and E44 differ in their ability to inhibit the $\mathrm{mAb}$ in group $\mathrm{B}$.

\section{IFMA combinations of antibody pairs}

The results from the study of all antibody pairs in fluorometric assay combinations are shown in Table 2 . The results indicate that antibodies belonging to groups $\mathrm{A}, \mathrm{B}$, and $\mathrm{C}$ are best as solid phase antibodies, while group $\mathrm{D}$ and $\mathrm{E}$ mAbs behave best as tracer antibodies. There are, however, a few other acceptable assay combinations, the other way around for solid phase and tracer mAbs from these groups. Only mAb I24 (group B) can be used both as solid phase and tracer antibody to establish an immunoassay with suitable response signals.

\section{Antibody combinations in the presence of antithyroglobulin autoantibodies}

One of the purposes of this study was to select antibodies with minor influence of autoantibodies to $\mathrm{Tg}$ which may be present in patient serum. Thus, pairs of antibodies were tested for their ability to determine $\mathrm{Tg}$ in the presence of human $\mathrm{TgAb}$. Initial IRMA measurements of Tg in the presence of autoantibodies indicated that $\mathrm{mAb} \mathrm{E} 40$ was superior to $\mathrm{mAb} \mathrm{I} 25$, both belonging to group C. Results are not shown. Therefore, the latter antibody was omitted in further experiments. Although E45 and E47 were in the same group (group E), their exceptional ability to make sensitive assays made it reasonable to include both antibodies in the further testing. Thus, we chose I15, I24, or E40 as solid phase antibodies (groups A, B, and C), respectively, with either E44, E45, or E47 as tracer antibodies (groups D and E), respectively, in the presence of a selection of patient sample containing autoantibodies. Figure 1 shows the results of these analyses. Eight individual patient sera ( $\mathrm{TgAb}$ ranging from 261 to $1756 \mathrm{kU} / \mathrm{l})$ and a pool of 35 sera $(\mathrm{TgAb}=7224 \mathrm{kU} / \mathrm{l})$ were included in IFMA combinations of the six monoclonal antibodies. Analytical recovery for the IFMA combinations differed considerably. Also, some of the individual sera were more inhibiting than others for all $\mathrm{mAb}$ combinations tested, and the pooled serum was highly inhibiting for all combinations tested. However, no combination was unaffected by all the autoantibodies tested. The IFMA combinations of E40 with E45 in Fig. $1 \mathrm{~b}$ gave generally the best responses for a given concentration of $\mathrm{Tg}$, while antibody combinations of E40 with E44 and I24 with E45 (Fig. 1a, h) also distinguished by the best responses in the assay for a given concentration of $\mathrm{Tg}$. Thus, these results indicate that E40, I24, E44, and E45 are the best candidate antibodies for a sensitive and robust $\mathrm{Tg}$ assay.

\section{Binding kinetics of the Tg antibodies E40, E44, E45, E47, I15, and 124}

The binding kinetics of the Tg antibodies were estimated using two different methods, (1) from the concentration of free antibody needed to achieve half-maximal binding of $\mathrm{Tg}$ and (2) by SPR analysis using the BIAcore 3000 SPR biosensor (Table 3 ). The $K_{\mathrm{D}}$ values estimated from equilibrium analysis correlate quite well with the values obtained using SPR analysis. Both methods showed that all antibodies (E44, $\mathrm{E} 45, \mathrm{E} 47, \mathrm{I} 15$, and I24) had very high affinity for Tg with $K_{\mathrm{D}}$ values $\leq 6 \times 10^{-10}$ except for E40 which had a $K_{\mathrm{D}}$ of $1 \times 10^{-9}$. The equilibrium analysis indicated that E45 and $\mathrm{I} 24$ had the highest affinity for Tg with $K_{\mathrm{D}}=2 \times 10^{-10}$ for both, while the SPR analysis indicated that E47 and I15 had the highest $\mathrm{Tg}$ affinity with $K_{\mathrm{D}}=1.1 \times 10^{-10}$ and $K_{\mathrm{D}}=2.6 \times 10^{-10}$, respectively. 
Table 1 Cross-inhibition

\begin{tabular}{|c|c|c|c|c|c|c|c|c|c|c|}
\hline \multirow[t]{3}{*}{ Group } & \multirow[t]{3}{*}{ Solid phase $\mathrm{mAb}$} & \multicolumn{9}{|c|}{ Inhibiting antibodies } \\
\hline & & \multirow{2}{*}{$\begin{array}{l}\text { Group A } \\
\text { I15 }\end{array}$} & \multirow{2}{*}{$\begin{array}{l}\text { Group B } \\
\mathrm{I} 24\end{array}$} & \multicolumn{3}{|c|}{ Group C } & \multicolumn{2}{|c|}{ Group D } & \multicolumn{2}{|c|}{ Group E } \\
\hline & & & & $\mathrm{I} 25$ & $\mathrm{E} 40$ & E41 & E39 & E44 & E45 & $\mathrm{E} 47$ \\
\hline A & I15 & 100 & 49 & 50 & 61 & 45 & 34 & 39 & 40 & 51 \\
\hline B & $\mathrm{I} 24$ & 59 & 99 & 47 & 53 & 35 & 0 & 23 & 20 & 41 \\
\hline \multirow[t]{3}{*}{$\mathrm{C}$} & $\mathrm{I} 25$ & 58 & 49 & 99 & 98 & 60 & 14 & 36 & 26 & 46 \\
\hline & $\mathrm{E} 40$ & 56 & 51 & 98 & 99 & 64 & 35 & 44 & 40 & 51 \\
\hline & E41 & 58 & 52 & 90 & 95 & 98 & 48 & 54 & 37 & 50 \\
\hline \multirow[t]{2}{*}{$\mathrm{D}$} & E39 & 57 & 49 & 63 & 65 & 66 & 97 & 97 & 57 & 64 \\
\hline & E44 & 55 & 48 & 73 & 74 & 70 & 97 & 99 & 38 & 58 \\
\hline \multirow[t]{2}{*}{$\mathrm{E}$} & E45 & 59 & 45 & 59 & 58 & 54 & 63 & 77 & 99 & 99 \\
\hline & E47 & 57 & 41 & 51 & 58 & 49 & 62 & 71 & 98 & 99 \\
\hline
\end{tabular}

Complete inhibition $>80 \%$ is indicated in bold type

\section{IFMA combinations with multiple mAbs as catcher and tracer}

Some of the immunoassays based on a pair of two antibodies were superior to others in detecting serum Tg in the presence of autoantibodies. However, none of these assays were unaffected by every analyzed sample containing human $\mathrm{TgAb}$. Therefore, immunoassays combining multiple mAbs as catcher and/or tracer were evaluated. Here, we included the same six antibodies as above without excluding I15 and E47 for now. First, combinations of two or three solid phase antibodies with each of the tracer antibody candidates were tested for their performance expressed by the responses obtained in a calibration curve between 0 and $1342 \mu \mathrm{g} / \mathrm{l}$. Only slight differences were seen between the calibration curves, but the combination of E40 and E24 was recognized as the best solid phase combination, results not shown. Further, combination of tracer antibodies E44 and E45 and E44 and E47, respectively, compared to only E45 were tested with the best solid phase combination $(\mathrm{E} 40+\mathrm{E} 24)$. Combining two tracer antibodies gave higher responses for the calibration curve compared to only one tracer, but no significantly differences were observed between the

Table 2 Immunofluorometric assay combinations of monoclonal antibodies

\begin{tabular}{|c|c|c|c|c|c|c|c|c|}
\hline \multirow[t]{3}{*}{ Group } & \multirow{3}{*}{$\begin{array}{l}\text { Solid } \\
\text { phase } \\
\text { mAbs }\end{array}$} & \multicolumn{7}{|c|}{ Tracer mAbs } \\
\hline & & \multirow{2}{*}{$\begin{array}{c}\text { Group } \\
\text { A } \\
\text { Eu-I15 }\end{array}$} & \multirow{2}{*}{$\begin{array}{c}\text { Group } \\
\text { B } \\
\text { Eu-I24 }\end{array}$} & \multicolumn{2}{|c|}{ Group C } & \multirow{2}{*}{$\begin{array}{l}\text { Group D } \\
\text { Eu-E44 }\end{array}$} & \multicolumn{2}{|c|}{ Group E } \\
\hline & & & & Eu-I25 & Eu-E40 & & Eu-E45 & Eu-E47 \\
\hline \multirow[t]{2}{*}{ A } & Bio-I15 & & & & & & & \\
\hline & & -412 & 1685 & 568 & 30098 & 39053 & 44750 & 52890 \\
\hline \multirow[t]{2}{*}{ B } & Bio-I24 & & & & & & & \\
\hline & & 7900 & 23218 & -96 & 17355 & 28971 & 31264 & 36909 \\
\hline \multirow[t]{4}{*}{$\mathrm{C}$} & Bio-I25 & & & & & & & \\
\hline & & 18938 & 24305 & 22 & 1980 & 30352 & 32140 & 41971 \\
\hline & Bio-E40 & & & & & & & \\
\hline & & 15185 & 26874 & -102 & -2214 & 25380 & 33130 & 45093 \\
\hline \multirow[t]{2}{*}{$\mathrm{D}$} & Bio-E44 & & & & & & & \\
\hline & & 11189 & 31560 & 664 & 28716 & 2604 & 36203 & 35802 \\
\hline \multirow[t]{4}{*}{$\mathrm{E}$} & Bio-E45 & & & & & & & \\
\hline & & 14895 & 24347 & -1322 & 22370 & 27097 & 2477 & 2730 \\
\hline & Bio-E47 & & & & & & & \\
\hline & & 19528 & 37379 & 950 & 28995 & 32317 & 36 & 1707 \\
\hline
\end{tabular}

The antibodies that were further used for testing analytical recovery in the presence of interfering autoantibodies are highlighted in bold. A Tg concentration of $18 \mu \mathrm{g} / \mathrm{ml}$ is used in the experiment. White: cps $(18 \mu \mathrm{g} / \mathrm{ml}$-blank $) \leq 10,000$, light grey: cps $>10,000 \leq 30,000$, grey: cps $>30,000 \leq 40,000$, dark grey: cps $>40,000$ 

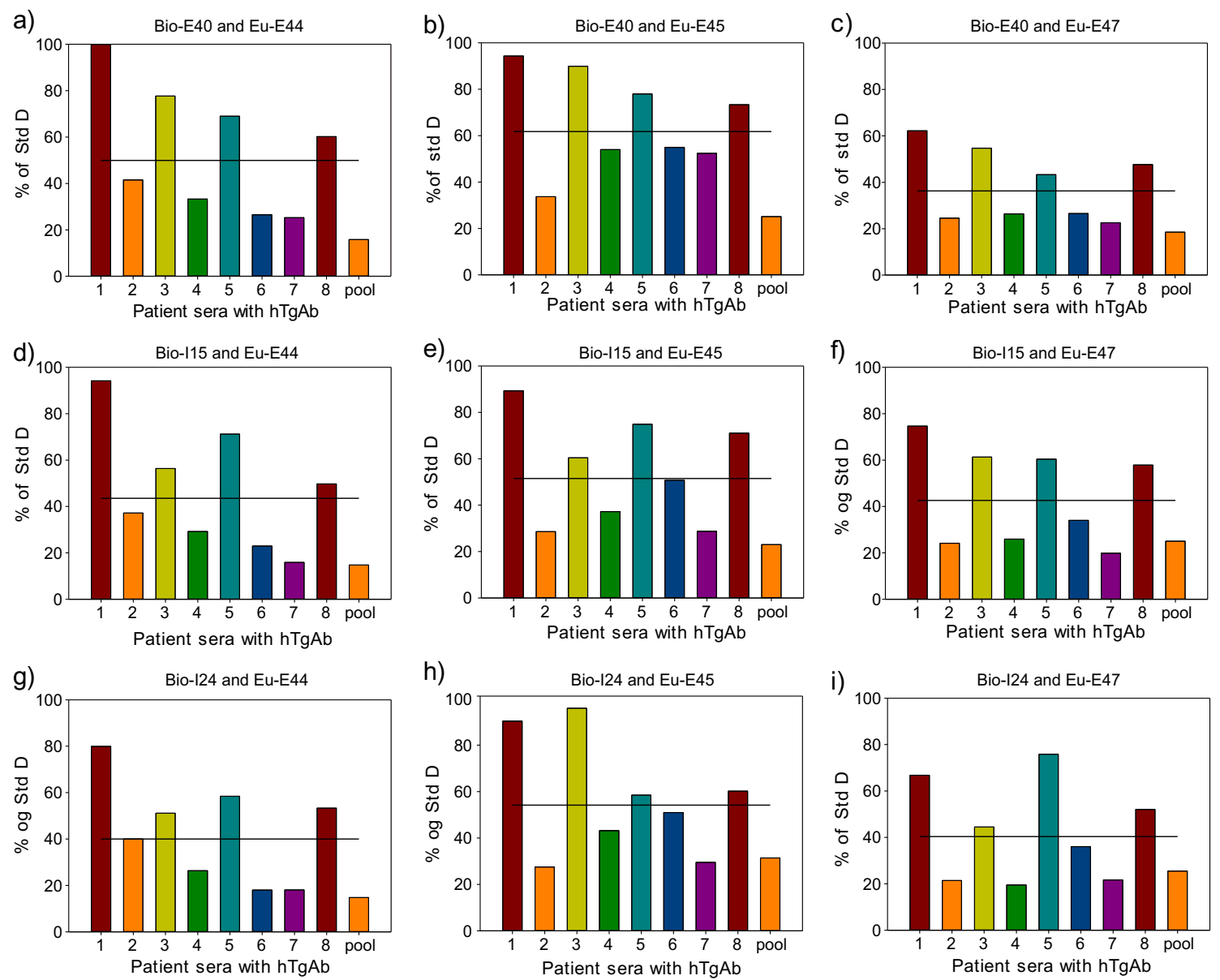

Fig. 1 Antibody combinations in the presence of eight individual patient samples (TgAb ranging from 261 to $1756 \mathrm{kU} / \mathrm{l})$ and one pool of patient samples $(\mathrm{TgAb}=7224 \mathrm{kU} / \mathrm{l})$. A Tg concentration of $18 \mu \mathrm{g} / \mathrm{ml}$ is used in

the experiment and the results shown as percent analytical recovery. Lines representing mean analytical recoveries are also included in each figure

combinations E44 and E45 versus E44 and E47, results not shown. Thus, because E45 were shown to be more unaffected by human autoantibodies than E47, antibody E45 was considered a better tracer candidate than E47.

The final IFMA assay was therefore based on E40 and I24 as solid phase antibodies in combination with E44 and E45 as tracer antibodies.

Table 3 Binding kinetics and affinities for the Tg antibodies E40, E44, $\mathrm{E} 45, \mathrm{E} 47, \mathrm{I} 15$, and $\mathrm{I} 24$

\begin{tabular}{|c|c|c|c|c|}
\hline \multirow[t]{2}{*}{ MAb } & \multicolumn{3}{|c|}{ SPR analysis } & \multirow{2}{*}{$\begin{array}{l}\text { Estimates from } \\
\text { equilibrium } \\
\text { analysis } \\
K_{\mathrm{D}} \\
{[\mathrm{M}]}\end{array}$} \\
\hline & $\begin{array}{l}K_{\mathrm{a}} \\
{\left[\mathrm{M}^{-1} \mathrm{~s}^{-1}\right]}\end{array}$ & $\begin{array}{l}K_{\mathrm{d}} \\
{\left[\mathrm{M}^{-1} \mathrm{~s}^{-1}\right]}\end{array}$ & $\begin{array}{l}K_{\mathrm{D}} \\
{[\mathrm{M}]}\end{array}$ & \\
\hline E40 & $3.32 \times 10^{5}$ & $3.69 \times 10^{-4}$ & $1.1 \times 10^{-9}$ & $1.2 \times 10^{-9}$ \\
\hline E44 & $3.14 \times 10^{5}$ & $1.29 \times 10^{-4}$ & $4.1 \times 10^{-10}$ & $3 \times 10^{-10}$ \\
\hline E45 & $4.99 \times 10^{5}$ & $1.98 \times 10^{-4}$ & $4.0 \times 10^{-10}$ & $2 \times 10^{-10}$ \\
\hline E47 & $2.95 \times 10^{5}$ & $3.23 \times 10^{-5}$ & $1.1 \times 10^{-10}$ & $6 \times 10^{-10}$ \\
\hline I15 & $2.46 \times 10^{5}$ & $6.29 \times 10^{-5}$ & $2.6 \times 10^{-10}$ & $3 \times 10^{-10}$ \\
\hline $\mathrm{I} 24$ & $4.24 \times 10^{5}$ & $2.15 \times 10^{-4}$ & $5.1 \times 10^{-10}$ & $2 \times 10^{-10}$ \\
\hline
\end{tabular}

\section{Performances of the final IFMA assay for Tg}

Assay The final assay was automated on an AutoDelfia instrument. To minimize the risk of heterophilic antibody interference, modifications were introduced including the use of $\left.\mathrm{F}(\mathrm{ab})_{2}\right)_{2}$ fragments as solid phase and irrelevant immunoglobulin buffer additives [14]. Patient serum diluted to $0.2,0.45$, and $42.9 \mu \mathrm{g} / \mathrm{l} \mathrm{Tg}$ was used to determine optimal assay kinetics. The signals reached a plateau after a 30-min incubation for the $\left(\mathrm{Fab}^{\prime}\right)_{2}$ capture reagents, $1 \mathrm{~h}$ for the antigen, and a final incubation of $1 \mathrm{~h}$ with the $\mathrm{Eu}^{3+}$-labelled tracer antibodies (data not shown). A typical calibration curve is presented in Fig. 2 together with an intra-assay precision profile. The assay displayed a wide dynamic range with linearity up to $1342 \mu \mathrm{g} / \mathrm{l}$.

Analytical validation LoB was determined from 77 separate runs and calculated as $0.02 \mu \mathrm{g} / \mathrm{l}$. LoD was determined from the LoB and SD of a sample containing low concentration of $\operatorname{Tg}(0.26 \mu \mathrm{g} / \mathrm{l})$ in 105 separate runs and estimated to $0.05 \mu \mathrm{g} / \mathrm{l}$. The functional sensitivity, defined as the lowest $\mathrm{Tg}$ concentration measured with CV of $20 \%$, was assessed to be $0.1 \mu \mathrm{g} / 1$ 
Fig. 2 Calibration curve (black circle) and imprecision profile (black down-pointing triangle) for the final $\mathrm{Tg}$ assay. The calibration curve is linear over a range of $0.9-1342 \mu \mathrm{g} / \mathrm{l}$ $\left(y=0.96 x+3.81, R^{2}=1\right)$. The imprecision profile shows $\mathrm{CV}<10 \%$ over the entire working range $(N=2664)$

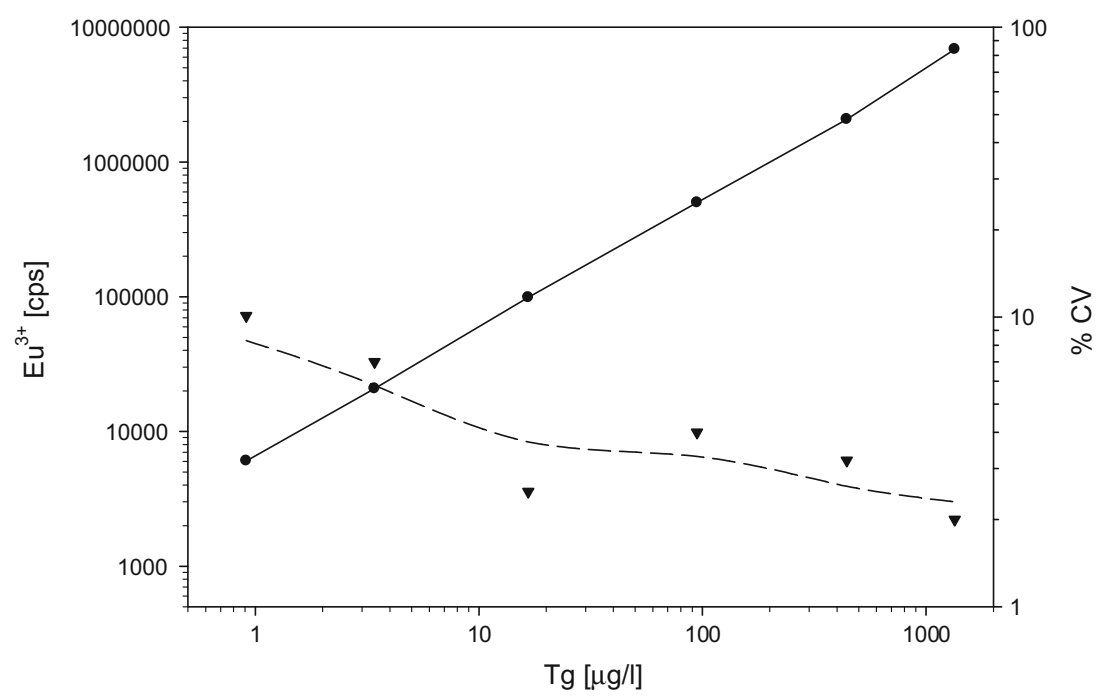

after 9 months of evaluation time using several different reagent and calibrator lots. Within-run and total imprecision of the assay were determined with 2664 samples in 60 separate runs. The variation between replicates was acceptable with a total imprecision of less than $10 \%$ (Fig. 2). The measured mean concentrations of $\mathrm{Tg}$ controls were $0.26,0.54$, and $45 \mu \mathrm{g} / \mathrm{l}$. The within-run imprecisions were $6.3,4.3$, and $2.3 \%$, and total imprecisions were $6.9,6.9$, and $3.6 \%$, respectively. Linearity on dilution resulted in apparent mean recoveries of $67-95 \%$ of expected in zero calibrator.

\section{Comparison of the new IFMA for Tg with two well-established $\mathrm{Tg}$ assays}

Concentrations of Tg in 241 serum samples were determined simultaneously by the newly developed IFMA and two commercially available immunoassays for $\mathrm{Tg}$, a homogenous assay (Brahms Kryptor) and a chemiluminescence assay (Roche Diagnostics). Out of these samples, 74 were from patients with low initial $\mathrm{Tg}$ values and negative/low values of human $\operatorname{TgAb}(<50 \mathrm{kU} / \mathrm{l})$ and who had undergone rhTSH stimulation. We analyzed two to three samples per patients, resulting in a total of 210 samples. The final 31 samples were from 31 randomly selected patients with measurable $\mathrm{TgAb}$ values $>50 \mathrm{kU} / 1$ (ranging from 50 to $2934 \mathrm{kU} / \mathrm{l}$ ). The correlation between the new IFMA and the Kryptor assay was $y=a x+b$ with $a=1.06(95 \% \mathrm{CI}=[1.02 ; 1.09])$ and $b=-0.09((95 \%$ $\mathrm{CI}=[-0.13 ;-0.04]), \rho=0.79(95 \% \mathrm{CI}=[0.74 ; 0.84]))$ (Fig. 3). Due to inadequate sample volume in two of the samples, only 239 samples were evaluated in the Roche assay. The correlation between the new IFMA and the Kryptor assay was $y=a x+b$ with $a=0.93(95 \% \mathrm{CI}=[0.91 ; 0.96])$ and $b=-0.20$ $((95 \% \mathrm{CI}=[-0.23 ;-0.16]), \rho=0.82(95 \% \mathrm{CI}=[0.78 ; 0.86]))$ (Fig. 4). Mean difference between the new IFMA and the Kryptor assay was $0.059 \mu \mathrm{g} / \mathrm{l}(95 \% \mathrm{CI}=[-0.032 ; 0.15 \mu \mathrm{g} /$ 1]), and thus, the new IFMA method and the Kryptor assay gave similar results. Mean difference between the new IFMA and the Roche assay was $-0.80 \mu \mathrm{g} / 1(95 \% \mathrm{CI}=[-1.24$; $-0.35 \mu \mathrm{g} / \mathrm{l}]$ ). Thus, the new IFMA tended to give lower results than the Roche assay by between -1.24 and $-0.35 \mu \mathrm{g} / \mathrm{l}$.

\section{Discussion}

Thyroglobulin is a specific tumor marker for follow-up of patients with DTC which have undergone total thyroidectomy with or without postoperative 131-iodine ablation, and the sensitivity of a Tg assay is important for a correct interpretation of clinical significance of minimal changes in serum $\mathrm{Tg}$.

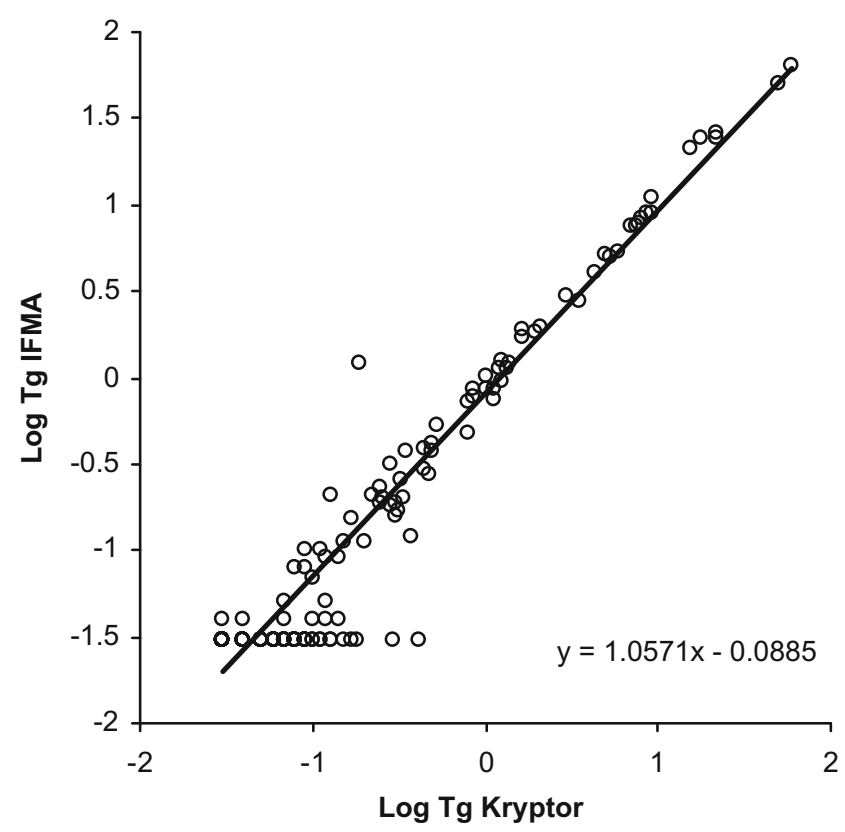

Fig. 3 Correlation between the new TR-IFMA and a homogenous assay for detection of Tg (Brahms Kryptor) in 241 serum samples. Deming regression line is included 


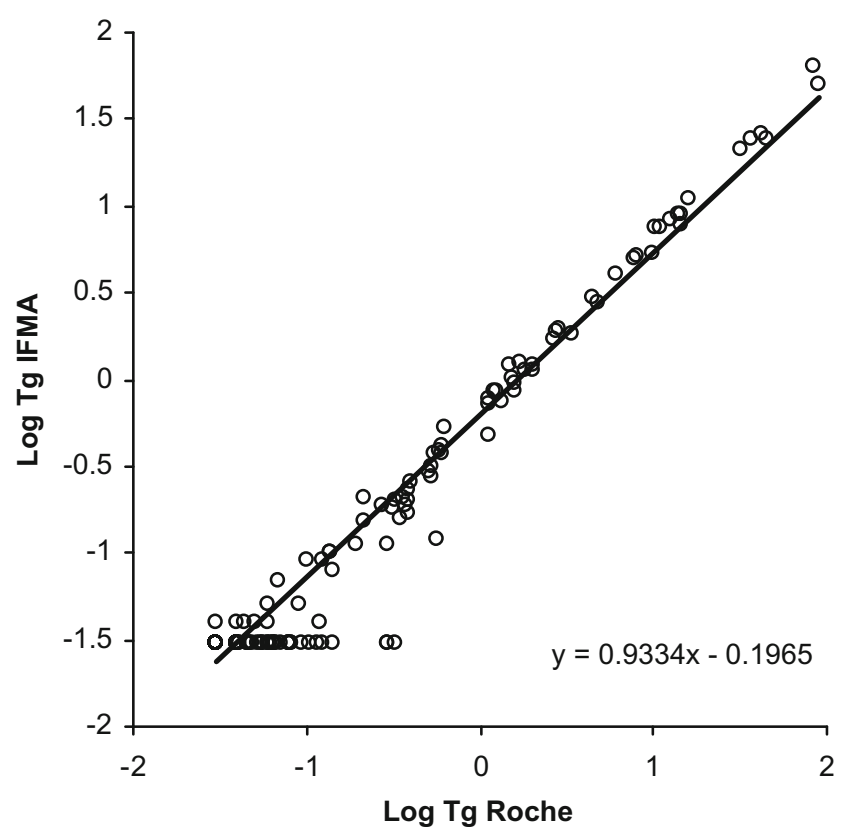

Fig. 4 Correlation between the new TR-IFMA and a chemiluminescence assay for detection of Tg (Roche Diagnostics) in 239 serum samples. Deming regression line is included

However, the presence of anti-Tg autoantibodies may mask the epitopes used by reagent antibodies in an immunoassay and cause an underestimation of the thyroglobulin concentration. The only currently available methodology that could completely eliminate interference of TgAbs with the measurement of Tg appears to be mass spectrometry. Liquid chromatography-tandem mass spectrometry (LC-MS MS) has shown promising results for measuring Tg in biological samples with higher resistance against antibody interference than the immunoassays [8]. However, because these methods do not have the necessary functional sensitivity, have a complex and manual workflow, and are not universally available, Tg measurements with LC-MS MS should be restricted for TgAb-positive serum samples [7, 8]. Thus, there is apparently still a need for a highly sensitive $\mathrm{Tg}$ immunoassay with less interference by $\mathrm{Tg}$ autoantibodies.

To make a new and improved immunoassay for $\mathrm{Tg}$, we have used a novel approach and selected monoclonal antibodies in the presence of autoantibodies from patients with thyroid cancer. After screening approximately 2000 hybridomas, nine antibodies were selected according to their ability to bind $\mathrm{Tg}$ in the presence of anti- $\mathrm{Tg}$ autoantibodies. From their crossinhibition patterns, these antibodies were classified into five epitope groups, A to E, where group D is comprised by two subgroups. This is in agreement with earlier studies by Ruf et al. and Piechaczyk et al. where ten and 15 murine monoclonal antibodies against human $\mathrm{Tg}$ were classified into six epitope clusters, respectively $[15,16]$. In the study by Ruf et al., two closely related groups failed to be classified in the same epitope cluster because one antibody displayed an asymmetric cross-inhibition pattern with one antibody in the other group, resembling the subdivision of our group D due to differences between mabs E39 and E44 in their ability to inhibit mAb I24 in group B. Our choice of antibodies from most of the defined epitope groups indicates that we have a representative panel of mAbs when selecting suitable antibody pairs for a new IFMA.

It is well known that some parts of the Tg molecule are more prone to autoantibody interference than other, and it has been shown that $\mathrm{TgAbs}$ recognize overlapping epitopes in an immunodominant region on the $\mathrm{Tg}$ dimer with two major and three minor epitopic regions [17]. There has also been shown that epitope recognition patterns of $\mathrm{TgAb}$ are different in individuals who are euthyroid or have clinical disease and that epitope recognition pattern may be of clinical and prognostic relevance in TgAb-positive DTC patients [18]. TgAbs in patients with autoimmune thyroid diseases react with a few of the antigenic determinants on $\mathrm{Tg}$, and their serum levels are elevated compared to serum levels in non-autoimmune diseases $[19,20]$. On the contrary, $\operatorname{TgAbs}$ in patients with thyroid cancer and healthy individuals appear to be more heterogeneous [19, 21, 22]. However, several studies have also been able to identify restricted $\mathrm{TgAb}$ recognition patterns in patients with thyroid cancer and indicated that it may be possible to distinguish between patients with different thyroid diseases and healthy individuals on the basis of the differences in $\mathrm{TgAb}$ specificities [20,23]. Finally, because of the large size and structural complexity of the thyroglobulin molecule, the antigenic composition of Tg is still not well understood. Thus, it seems to be impossible to make an immunoassay for $\mathrm{Tg}$ completely protected against human autoantibodies. However, our approach for minimizing the influence of human $\operatorname{TgAb}$ was to test and select antibody pairs in the presence of human $\mathrm{TgAb}$ in the form of individual sera and a pool of sera consisting of 35 individual sera containing human $\mathrm{TgAb}$. Consequently, some of the individual sera as well as the pooled serum were more inhibiting than others for all $\mathrm{mAb}$ combinations tested, and the pooled serum was most likely dominated by a few individual sera with highly elevated concentrations of human $\mathrm{TgAb}$. Because some parts of the $\mathrm{Tg}$ molecule are more prone to autoantibody interference than other, this was as expected. In the final IFMA, we combined four antibodies against four distinct epitopes on $\mathrm{Tg}$ to obtain the highest sensitivity and the best possible protection against autoantibodies. Consequently, by combining several antibodies from different epitope groups, we have increased the probability of avoiding the negative effect of autoantibodies.

In the final assay, E40 and I24 were used as solid phase antibodies in combination with E44 and E45 as tracer antibodies. The antibodies were thoroughly characterized, and the binding kinetics of the antibodies was estimated from equilibrium analysis and SPR analysis. All four assay antibodies had acceptable binding affinities for construction of an immunoassay $\left(2 \times 10^{-10}<K_{\mathrm{D}}<1 \times 10^{-9}\right)$, and the differences between 
the $K_{\mathrm{D}}$ values obtained with the individual methods were within expected range when using two different methods.

With a functional sensitivity of $0.1 \mu \mathrm{g} / \mathrm{l}$ and a total imprecision of the assay less than $10 \%$, our assay fulfills the criteria of a highly sensitive assay for $\mathrm{Tg}$, which is useful for management of thyroid cancer [7]. As mentioned earlier, the sensitivity of the assay is important in the follow-up of DTC patients, and for the clinician, even $\mathrm{Tg}$ values below $0.2 \mu \mathrm{g} / \mathrm{l}$ may suggest no residual thyroid tissue or recurrence/metastasis of the cancer after treatment. In a study by Iervasi et al. [19], it was shown that $\mathrm{Tg}$ assays with sensitivities ranging between 0.1 and $1 \mu \mathrm{g} / \mathrm{l}$ may allow for earlier identification, particularly for patients with minimal amounts of circulating Tg [24]. It has also been shown that monitoring $\mathrm{Tg}$ with a sensitive immunoassay had comparable sensitivity to recombinant human TSH-stimulated Tg in follow-up of thyroid cancer patients [25]. It is likely that very low $\mathrm{Tg}$ concentrations do not require immediate treatment and that serial measurements of serum $\mathrm{Tg}$ are more informative than an absolute single value and have additional clinical benefit [26]. Thus, our new hsTg assay may have improved clinical value for detection of recurrent disease and for serial measurements in long-term follow-up.

Measuring $\mathrm{Tg}$ in samples with $\operatorname{TgAb}$ is still challenging; however, a measurable $\mathrm{Tg}$ value in a $\mathrm{TgAb}$-positive patient gives the clinician valuable information even though the $\mathrm{Tg}$ value might be false low leading to further examination as ultrasonography.

Finally, there is a good agreement between the new IFMA assay and the established Tg assays from Brahms Kryptor and Roche Diagnostics; however, the new IFMA tended to give lower results than the Roche assay by between -1.24 and $-0.35 \mu \mathrm{g} / \mathrm{l}$. Differences in the assay antibodies characteristics may explain these discrepancies even though both assays are traceable to the same CRM 457. In a review by Clark et al., they state that although many assays are traceable to the same reference material CRM 457, a wide scatter of results was obtained [27]. The CRM 457 was shown to contain both intact $\mathrm{Tg}$ molecules and smaller molecular forms [27]. Thus, the different assay antibodies may differently detect these variants of the Tg molecule.

The potential underestimation of $\mathrm{Tg}$ concentrations caused by autoantibodies hampers the usefulness of sensitive thyroglobulin immunoassays; thus, this work can potentially improve the clinical utility of the hsTg assay.

Open Access This article is distributed under the terms of the Creative Commons Attribution 4.0 International License (http:// creativecommons.org/licenses/by/4.0/), which permits unrestricted use, distribution, and reproduction in any medium, provided you give appropriate credit to the original author(s) and the source, provide a link to the Creative Commons license, and indicate if changes were made.

\section{References}

1. Van Herle AJ, Vassart G, Dumont JE. Control of thyroglobulin synthesis and secretion (first of two parts). N Engl J Med. 1979;301(5):239-49.

2. Van Herle AJ, Vassart G, Dumont JE. Control of thyroglobulin synthesis and secretion (second of two parts). N Engl J Med. 1979;301(6):307-14.

3. Mazzaferri EL. Histologic variants of papillary thyroid carcinoma. Endocr Pract. 2001;7(2):139-42.

4. Pellegriti G, Frasca F, Regalbuto C, Squatrito S, Vigneri R. Worldwide increasing incidence of thyroid cancer: update on epidemiology and risk factors. J Cancer Epidemiol. 2013;2013: 965212.

5. Malandrino P, Latina A, Marescalco S, Spadaro A, Regalbuto C, Fulco RA, et al. Risk-adapted management of differentiated thyroid cancer assessed by a sensitive measurement of basal serum thyroglobulin. J Clin Endocrinol Metab. 2011;96(6):1703-9.

6. Chindris AM, Diehl NN, Crook JE, Fatourechi V, Smallridge RC. Undetectable sensitive serum thyroglobulin $(<0.1 \mathrm{ng} / \mathrm{ml})$ in 163 patients with follicular cell-derived thyroid cancer: results of rhTSH stimulation and neck ultrasonography and long-term biochemical and clinical follow-up. J Clin Endocrinol Metab. 2012;97(8):2714-23.

7. Giovanella L, Feldt-Rasmussen U, Verburg FA, Grebe SK, Plebani M, Clark PM. Thyroglobulin measurement by highly sensitive assays: focus on laboratory challenges. Clin Chem Lab Med. 2014.

8. Spencer C, Petrovic I, Fatemi S, LoPresti J. Serum thyroglobulin (Tg) monitoring of patients with differentiated thyroid cancer using sensitive (second-generation) immunometric assays can be disrupted by false-negative and false-positive serum thyroglobulin autoantibody misclassifications. J Clin Endocrinol Metab. 2014;99(12):4589-99.

9. Spencer C, Petrovic I, Fatemi S. Current thyroglobulin autoantibody (TgAb) assays often fail to detect interfering $\mathrm{TgAb}$ that can result in the reporting of falsely low/undetectable serum Tg IMA values for patients with differentiated thyroid cancer. J Clin Endocrinol Metab. 2011;96(5):1283-91.

10. Stahli C, Staehelin T, Miggiano V, Schmidt J, Haring P. High frequencies of antigen-specific hybridomas: dependence on immunization parameters and prediction by spleen cell analysis. J Immunol Methods. 1980;32(3):297-304.

11. Dajani LK, Paus E, Warren DJ. Development of a rapid and sensitive immunofluorometric assay for glutathione S-transferase A. Clin Chem. 2001;47(5):867-73.

12. Milenic DE, Esteban JM, Colcher D. Comparison of methods for the generation of immunoreactive fragments of a monoclonal antibody (B72.3) reactive with human carcinomas. J Immunol Methods. 1989;120(1):71-83.

13. Armbruster DA, Pry T. Limit of blank, limit of detection and limit of quantitation. Clin Biochem Rev. 2008;29 Suppl 1:S49-52.

14. Bjerner J, Nustad K, Norum LF, Olsen KH, Bormer OP. Immunometric assay interference: incidence and prevention. Clin Chem. 2002;48(4):613-21.

15. Ruf J, Carayon P, Sarles-Philip N, Kourilsky F, Lissitzky S. Specificity of monoclonal antibodies against human thyroglobulin; comparison with autoimmune antibodies. EMBO J. 1983;2(10): 1821-6.

16. Piechaczyk M, Chardes T, Cot MC, Pau B, Bastide JM. Production and characterization of monoclonal antibodies against human thyroglobulin. Hybridoma. 1985;4(4):361-7.

17. Latrofa F, Phillips M, Rapoport B, McLachlan SM. Human monoclonal thyroglobulin autoantibodies: epitopes and immunoglobulin genes. J Clin Endocrinol Metab. 2004;89(10):5116-23. 
18. Lupoli GA, Okosieme OE, Evans C, Clark PM, Pickett AJ, Premawardhana LD, et al. Prognostic significance of thyroglobulin antibody epitopes in differentiated thyroid cancer. J Clin Endocrinol Metab. 2015;100(1):100-8.

19. Ruf J, Carayon P, Lissitzky S. Various expressions of a unique antihuman thyroglobulin antibody repertoire in normal state and autoimmune disease. Eur J Immunol. 1985;15(3):268-72.

20. Piechaczyk M, Bouanani M, Salhi SL, Baldet L, Bastide M, Pau B, et al. Antigenic domains on the human thyroglobulin molecule recognized by autoantibodies in patients' sera and by natural autoantibodies isolated from the sera of healthy subjects. Clin Immunol Immunopathol. 1987;45(1):114-21.

21. Bouanani M, Piechaczyk M, Pau B, Bastide M. Significance of the recognition of certain antigenic regions on the human thyroglobulin molecule by natural autoantibodies from healthy subjects. J Immunol. 1989;143(4):1129-32.

22. Rose NR, Bresler HS, Burek CL, Gleason SL, Kuppers RC. Mapping the autoepitopes of thyroglobulin. Isr J Med Sci. 1990;26(12):666-72.
23. Saboori AM, Caturegli P, Rose NR, Mariotti S, Pinchera A, Burek CL. Tryptic peptides of human thyroglobulin: II. Immunoreactivity with sera from patients with thyroid diseases. Clin Exp Immunol. 1994;98(3):459-63.

24. Iervasi A, Iervasi G, Ferdeghini M, Solimeo C, Bottoni A, Rossi L, et al. Clinical relevance of highly sensitive Tg assay in monitoring patients treated for differentiated thyroid cancer. Clin Endocrinol (Oxf). 2007;67(3):434-41.

25. Smallridge RC, Meek SE, Morgan MA, Gates GS, Fox TP, Grebe S, et al. Monitoring thyroglobulin in a sensitive immunoassay has comparable sensitivity to recombinant human TSH-stimulated thyroglobulin in follow-up of thyroid cancer patients. J Clin Endocrinol Metab. 2007;92(1): $82-7$.

26. Spencer CA, LoPresti JS, Fatemi S, Nicoloff JT. Detection of residual and recurrent differentiated thyroid carcinoma by serum thyroglobulin measurement. Thyroid. 1999;9(5): 435-41.

27. Clark P, Franklyn J. Can we interpret serum thyroglobulin results? Ann Clin Biochem. 2012;49(Pt 4):313-22. 